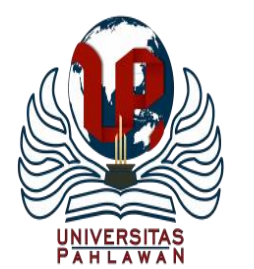

Edukatif : Jurnal Ilmu Pendidikan Volume 3 Nomor 2 Tahun 2021 Halm 480 - 486 EDUKATIF: JURNAL ILMU PENDIDIKAN

Research \& Learning in Education

https:/ledukatif.org/index.php/edukatif/index

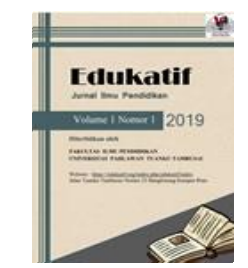

\title{
Kemandirian Belajar Melalui Metode Pembelajaran Project Based Learning Pada Mata Kuliah Media Pembelajaran Pendidikan Jasmani
}

\author{
Martiani \\ Universitas Dehasen Bengkulu, Indonesia \\ E-mail : annie.phaph@unived.ac.id
}

\begin{abstract}
Abstrak
Kemandirian belajar siswa merupakan suatu proses, dan proses ini hanya dapat dilaksanakan melalui kegiatan belajar. Model Project Based Learning merupakan pembelajaran inovatif yang berpusat pada peserta didik dan pembelajaran berbasis proyek ini dapat meningkatkan kemampuan berfikir kreatif melalui pengalaman nyata atau simulasi dan menjadi pembelajar yang otonom dan mandiri. Metode penelitian yang digunakan adalah metode penelitian deskriptif dengan pendekatan kuantitatif. Subjek yang digunakan pada penelitian ini sebanyak 78 mahasiswa, yaitu mahasiswa semester VI program studi pendidikan jasmani. Hasil pembahasan mengenai pembelajaran mahasiswa pendidikan jasmani dengan menggunakan metode belajar project based learning diperoleh data megenai indikator kemandirian belajar yaitu untuk indikator a) kemandirian belajar, b) memiliki kepercayaan diri, c) berperilaku disiplin, d) memiliki rasa tanggungjawab, e) berperilaku berdasarkan inisiatif sendiri, dan f) melakukan kontrol diri. Pada pembahasan kemandirian belajar yang timbul dari penerapan metode pembelajaran belajar project based learning yaitu sebesar $76.37 \%$ dengan kategori sangat positif. Disimpulkan bahwa mahasiswa program studi pendidikan jasmani mampu melaksanakan proses pembelajaran dengan penuh tanggung jawab, rasa percaya diri dan dapat menyelesaikan permasalahan dengan kerja proyek yang secara tidak langsung melatih untuk bertindak maupun berpikir mandiri dan kreatif pada mata kuliah media pembelajaran penjas.
\end{abstract}

Kata Kunci: Kemandirian Belajar, Project Based Learning.

\begin{abstract}
Student learning independence is a process, and this process can only be carried out through learning activities. The Project Based Learning Model is an innovative student-centered learning and project-based learning that can improve creative thinking skills through real experiences or simulations and become an autonomous and independent learner. The research method used is a descriptive research method with a quantitative approach. The subjects used in this study were 78 students, namely students of the sixth semester of the physical education study program. The results of the discussion regarding physical education student learning using project-based learning methods obtained data on indicators of learning independence, namely for indicators a) independent learning, b) having self-confidence, c) behaving in discipline, d) having a sense of responsibility, e) behaving based on initiative themselves, and f) exercise self-control. In the discussion of independent learning that arises from the application of the project based learning learning method, which is $76.37 \%$ with a very positive category. It was concluded that students of the physical education study program were able to carry out the learning process with full responsibility, self-confidence and be able to solve problems with project work that indirectly trained to act and think independently and creatively in Physical Education learning media courses.
\end{abstract}

Keywords: Independent Learning, Project Based Learning.

Copyright (c) 2021 Martiani

$\triangle$ Corresponding author

Email : annie.phaph@unived.ac.id

DOI : https://doi.org/10.31004/edukatif.v3i2.337

ISSN 2656-8063 (Media Cetak)

ISSN 2656-8071 (Media Online)

Edukatif : Jurnal Ilmu Pendidikan Vol 3 No 2 Tahun 2021 p-ISSN 2656-8063 e-ISSN 2656-8071 


\section{PENDAHULUAN}

Kemandirian merupakan perilaku individu yang mampu berinisiatif, mampu mengatasi masalah, mempunyai rasa percaya diri, bertanggung jawab dan dapat melakukan sesuatu sendiri tanpa tergantung pada orang lain. Bagi siswa yang sudah terbiasa mandiri dalam belajar ketika dihadapkan pada sebuah masalah akan cenderung bersikap tenang saat pengerjaan tugas-tugas belajar dikarenakan mereka mempunyai kepercayaan diri yang tinggi sehingga mereka tidak mudah terpengaruh oleh pendapat orang lain. Solusi ada karena adanya sebuah masalah, maka dari itu ketika dihadapkan pada suatu masalah diharapkan dapat berusaha untuk mencari solusinya dan tetap konsisten.

Kemandirian belajar mengandung arti belajar berdasarkan kemampuan yang dimiliki. Hal ini diperkuat oleh Sumarmo (2004) dalam (Sudiana et al., 2017) yang mengemukakan bahwa kemandirian belajar sebagai kemampuan memantau kemampuan sendiri, dan merupakan kerja keras personaliti manusia. Pengembangan kemandirian belajar sangat diperlukan dalam keberhasilan proses perkuliahan. Mahasiswa yang memiliki kemandirian belajar yang tinggi cenderung dapat belajar lebih baik, mampu memantau, mengevaluasi, dan mengatur jadwal belajarnya secara efektif. Lebih daripada itu, mahasiswa dapat memperkirakan waktu dalam mengerjakan tugas.

Faktanya seseorang yang tidak mempunyai kemandirian pasti tidak akan bisa berdiri sendiri dan tidak akan timbul suatu kepercayaan diri dalam menghadapi kehidupan khususnya dalam kehidupan di dunia pendidikan. (Yanti \& Surya, 2017) mengemukakan bahwa belajar mandiri ialah kegiatan belajar aktif, yang di dorong oleh motivasi mengenai suatu kompetensi yang dimiliki. Bagi siswa yang merupakan generasi penerus bangsa sangat diharapkan menumbuhkan sikap mandiri dan mempunyai semangat yang kuat untuk meningkatkan kualitas mutu pendidikan dalam pencapaian tujuan pendidikan sehingga proses pembelajaran dapat tercapai.

Menurut (Nurfadilah \& Hakim, 2019) upaya dalam bentuk kemandirian belajar siswa merupakan suatu proses, dan proses ini hanya dapat dilaksanakan melalui kegiatan belajar. Dalam hal ini guru perlu berupaya dengan melakukan variasi proses pembelajaran baik pendekatan, metode, atau model pembelajaran yang inovatif sehingga tujuan yang diharapkan berhasil. Penerapan strategi dan metode belajar yang tepat dapat mengarahkan siswa menjadi pribadi yang unggul, mandiri, bersemangat, dan berorentasi tinggi. Kemandirian memerlukan tanggung jawab, mereka yang mandiri adalah mereka yang bertanggung jawab, berinisiatif, memiliki keberanian, dan sanggup menerima resiko serta mampu menjadi pembelajaran terhadap dirinya sendiri. Sehingga indikator kemandirian belajar yaitu mempunyai kepercayaan terhadap diri sendiri, kegiatan belajarnya bersifat mengarahkan pada diri sendiri, mempunyai rasa tanggung jawab, mempunyai inisiatif untuk mengerjakan tugas sendiri.

Dalam upaya menjawab semua tantangan pembelajaran secara mandiri, maka metode yang dianggap cocok dengan karakteristik dan tujuan pada mata kuliah media pembelajaran penjas, serta perkembangan yang terjadi saat ini adalah model Project Based Learning. (Sevima, 2020) mengatakan salah satu metode pembelajaran yang digunakan pada masa pandemi saat sekarang ini yaitu menggunakan metode pembelajaran project based learning. Menurut Mendikbud, metode project based learning ini sangat efektif diterapkan untuk para pelajar dengan membentuk kelompok belajar kecil dalam mengerjakan projek, eksperimen, dan inovasi. Metode pembelajaran ini sangatlah cocok bagi pelajar yang berada pada zona kuning atau hijau. Dengan menjalankan metode pembelajaran yang satu ini, tentunya juga harus memerhatikan protokol kesehatan yang berlaku.

Project Based Learning merupakan salah satu model pembelajaran inovatif dan menekankan belajar kontekstual dan mengikutsertakan siswa melakukan investigasi secara kolaboratif, melalui kegiatan-kegiatan yang kompleks sehingga memotivasi siswa lebih aktif dan berinisiatif untuk memperoleh hal-hal yang mereka 
inginkan baik pada sisi pengetahuan, pemahaman, dan keterampilannya. Model Project Based Learning merupakan pembelajaran inovatif yang berpusat pada peserta didik (student centered) dan menempatkan guru sebagai motivator dan fasilitator, di mana peserta didik diberi peluang bekerja secara otonom mengkonstruksi belajarnya. Model project based learning mengarahkan peserta didik pada permasalahan secara langsung kemudian penyelesaiannya melibatkan kerja proyek yang secara tidak langsung aktif dan dilatih untuk bertindak maupun berpikir kreatif. Marlanti dalam (Kusadi et al., 2020). Pembelajaran berbasis proyek dapat meningkatkan kemampuan berfikir kreatif melalui pelibatan siswa dalam pengalaman nyata atau simulasi dan menjadi pembelajar yang otonom dan mandiri. Siswa mengembangkan kemampuan berpikir kreatifnya dengan memenuhi aspek berpikir kreatif seperti berpikir lancar (fluency) dalam menyelesaikan masalah, berpikir luwes (flexibility) untuk menghasilkan gagasan penyelesaian masalah, berpikir orisinal (originality) untuk memberikan gagasan yang berbeda dan berpikir terperinci (elaboration) untuk mengembangkan gagasanya (Munandar, 2009) dalam (Utami et al., 2015).

Menurut (Afriana, 2015) pembelajaran berbasis proyek merupakan model pembelajaran yang berpusat pada peserta didik dan memberikan pengalaman belajar yang bermakna bagi peserta didik. Pengalaman belajar peserta didik maupun konsep dibangun berdasarkan produk yang dihasilkan dalam proses pembelajaran berbasis proyek. Hakikat kerja proyek adalah berkelompok, maka pengembangan keterampilan belajar berlangsung diantara para siswa, yang berarti terjadi suatu aktivitas antar siswa yang satu dengan yang lainnya. Made Wena dalam (Lestari, 2016) juga menyatakan bahwa model project based learning adalah model pembelajaran yang memberikan kesempatan kepada pendidik untuk mengelola pembelajaran dikelas dengan melibatkan kerja proyek. Kerja proyek merupakan suatu bentuk kerja yang memuat tugas-tugas kompleks berdasarkan pertanyaan dan permasalahan yang sangat menantang dan menuntun peserta didik untuk merancang, memecahkan masalah, membuat keputusan, melakukan kegiatan investigasi, serta memberikan kesempatan peserta didik untuk bekerja secara mandiri. Tujuan pembelajaran project based learning menurut Karaduman dalam (Sudianto, 2018) menjadikan siswa menjadi mandiri dalam belajar, memiliki kemampuan pemecahan masalah, dan siswa dapat menghapai masalah yang kemungkinan terjadi dalam kehidupan sehari-hari. Berdasarkan beberapa pemaparan yang telah disampaikan, maka akan dibahas bagaimana kemandirian belajar mahasiswa pendidikan jasmani pada mata kuliah media pembelajaran penjas.

\section{METODE PENELITIAN}

Metode penelitian yang digunakan adalah metode penelitian deskriptif dengan pendekatan kuantitatif. (Sugiyono, 2008) menjelaskan bahwa penelitian deskriptif yaitu, penelitian yang dilakukan untuk mengetahui nilai variabel mandiri, baik satu variabel atau lebih (independen) tanpa membuat perbandingan, atau menghubungkan dengan variabel yang lain. (Turmuzi, 2021) Penelitian ini menggunakan jenis penelitian kualitatif deskriptif dan dieksplorasikan melalui data kuantitatif. Karakteristik penelitian kualitatif yaitu melakukan penelitian dalam kondisi yang alamiah, langsung ke sumber data, peneliti menjadi instrumen kunci, menyajikan data-data dalam bentuk kata-kata atau gambar dan tidak menekankan angka-angka, melakukan analisis data. Metode penelitian kualitatif ini tidak dimanipulasi oleh peneliti, analisis data berdasarkan fakta-fakta yang ditemukan dilapangan (Sugiyono, 2015) dalam (Yunitasari \& Hanifah, 2020).

Berdasarkan pengertian tersebut dapat disimpulkan bahwa penelitian deskriptif dilakukan dengan cara mencari informasi berkaitan dengan gejala yang ada, dijelaskan dengan jelas tujuan yang akan diraih, merencanakan bagaimana melakukan pendekatannya, dan mengumpulkan berbagai macam data sebagai bahan untuk membuat laporan. Dalam penelitian ini penulis ingin mengetahui gambaran mengenai aktivitas belajar yang muncul pada saat kegiatan pembelajaran yang menggunakan metode pembelajaran project based learning program. Pendekatan penelitian ini menggunakan pendekatan kuantitatif karena menggunakan angka, mulai dari pengumpulan data, penafsiran terhadap data tersebut, serta penampilan dari hasilnya. Subjek 
yang digunakan pada penelitian ini sebanyak 78 mahasiswa, yaitu mahasiswa semester VI program studi pendidikan jasmani.

Pengumpulan data dalam penelitian ini yaitu dengan angket kuesioner dengan menggunakan skala likert sebagai alternatif pilihan. Hasil dari data yang diperoleh akan dianalisis menggunakan analisis deskriptif kuantitatif dalam bentuk persentase. Hal ini untuk lebih memudahkan dalam membaca dan memahami data. Runtutan langkah yang dilakukan adalah menghitung skor perolehan tiap indikator. Setelah itu menghitung persentase jawaban dari tiap indikator kemudian ditarik kesimpulan akhirnya. Pedoman dari Sugiyono (2011) yaitu "semakin tinggi persentase responden maka semakin baik pula persepsi responden".

Tabel 1. Kriteria Interpretasi Skor

\begin{tabular}{ccc}
\hline No & Rentang Skor $(\%)$ & Kategori \\
\hline 1 & $76-100$ & Sangat Positif \\
\hline 2 & $51-75$ & Positif \\
\hline 3 & $26-50$ & Negatif \\
\hline 4 & $1-25$ & Sangat Negatif \\
\hline
\end{tabular}

\section{HASIL DAN PEMBAHASAN}

Analisis data hasil penelitian mengacu pada enam indikator kemandirian belajar yang dikembangkan oleh (Hidayati \& Listyani, 2007) yaitu: a) Ketidaktergantungan terhadap orang lain, b) Memiliki kepercayaan diri, c) Berperilaku disiplin, d) Memiliki rasa tanggung jawab, e) Berperilaku berdasarkan inisiatif sendiri, dan f) Melakukan kontrol diri, dijabarkan kecenderungan kemandirian belajar mahasiswa dengan metode pembelajaran project based learning.

Tabel 2. Analisis Kecenderungan Kemandirian Belajar Mahasiswa

\begin{tabular}{clcccc}
\hline No & \multicolumn{1}{c}{ Indikator } & $\begin{array}{c}\text { Skor } \\
\text { Ideal }\end{array}$ & $\begin{array}{c}\text { Skor } \\
\text { Aktual }\end{array}$ & Persentase & Kategori \\
\hline 1 & Ketidaktergantungan terhadap orang lain & 1270 & 958 & $74.59 \%$ & Positif \\
\hline 2 & Memiliki kepercayaan diri & 1270 & 986 & $77.63 \%$ & Sangat Positif \\
\hline 3 & Berperilaku disiplin & 1560 & 1302 & $83.46 \%$ & Sangat Positif \\
\hline 4 & Memiliki rasa tanggung jawab & 1560 & 1130 & $72.43 \%$ & Positif \\
\hline 5 & Berperilaku berdasarkan inisiatif sendiri & 1560 & 1172 & $75.12 \%$ & Positif \\
\hline 6 & Melakukan kontrol diri & 780 & 560 & $71.79 \%$ & Positif \\
\hline \multirow{2}{*}{ Total } & 8000 & 5760 & $76.37 \%$ & Sangat Positif \\
\hline
\end{tabular}

Dari hasil penelitian diperoleh total keseluruhan jawaban responden mengenai kemandirian belajar mahasiswa dengan metode pembelajaran project based learning yaitu sebesar $76.37 \%$ dengan kategori sangat positif.

Skala kemandirian belajar menunjukkan bahwa kecenderungan kemandirian belajar pada mahasiswa yang diterapkan project based learning termasuk dalam kategori positif sampai sangat negatif, ini dapat 
dilihat dari hasil analisis tiap indikator kemandirian belajar menunjukkan bahwa hampir semua responden memiliki intensitas kemandirian belajar. Dengan rincian tiap indikator, yaitu sebagai berikut:

Hasil analisis data dari tabel 2. persentase kemandirian belajar mahasiswa pendidikan jasmani pada indikator pertama ketidaktergantungan terhadap orang lain yaitu sebesar 74,59\%. Dapat disimpulkan bahwa secara umum kemandirian belajar mahasiswa pendidikan jasmani dalam indikator ketidaktergantungan terhadap orang lain dikategorikan positif. Hasil penelitian menunjukkan bahwa sebagian besar mahasiswa yang mengikuti pembelajaran dengan project based learning memiliki kertidaktergantungan pada orang lain positif. (Rifky, 2020) Mandiri adalah sikap tidak bergantung pada orang lain, kemandirian belajar diperlukan oleh peserta didik agar secara suka rela mau belajar tanpa adanya paksaan. Belajar mandiri bukanlah belajar individual, akan tetapi belajar yang menuntut kemandirian seorang siswa untuk belajar, belajar mandiri upaya untuk mengembangkan kebebasan kepada siswa dalam mendapat informasi dan pengetahuan yang tidak dikendalikan oleh orang lain. Siswa yang memiliki kemandirian yang kuat tidak akan mudah menyerah. Sikap kemandirian dapat ditunjukkan dengan adanya kemampuan menyelesaikan masalah yang dihadapi dengan tingkah laku. Dengan adanya perubahan tingkah laku maka siswa juga memiliki peningkatan dalam berfikir, menganggap bahwa dalam belajar harus bisa mandiri tanpa mengandalkan bantuan dari orang lain.

Pada indikator kedua, indikator memiliki kepercayaan diri yaitu sebesar 77,63\%. Dapat disimpulkan bahwa secara umum indikator memiliki kepercayaan diri pada mahasiswa pendidikan jasmani dinyatakan pada kategori sangat positif. Hasil penelitian menunjukkan bahwa mahasiswa sangat percaya diri dalam melakukan pembelajaran secara mandiri dengan menggunaan metode belajar project based learning yang tentunya didukung dengan materi pembelajaran yang telah sesuai dengan kebutuhan.

Pada indikator ketiga, indikator berperilaku disiplin yaitu sebesar 83,46\%. Dapat disimpulkan bahwa secara umum indikator berperilaku disiplin pada mahasiswa pendidikan jasmani dinyatakan pada kategori sangat positif. Hasil penelitian menunjukkan bahwa mahasiswa sangat disiplin dalam melakukan pembelajaran secara mandiri dengan menggunaan metode belajar project based learning dalam hal mengatur jadwal belajar secara mandiri dan sesuai target atau capaian pembelajaran. Menurut (Kurniawati, 2011) disiplin merupakan sesuatu yang berkenaan dengan pengendalian diri seseorang untuk mengikuti berbagai macam aturan atas kesadaran diri sendiri. Seperti halnya disiplin dalam belajar juga termasuk dalam kemauan belajar yang didorong dari dalam diri individu.

Pada indikator keempat, indikator memiliki rasa tanggungjawab yaitu sebesar 72,43\%. Dapat disimpulkan bahwa secara umum indikator memiliki rasa tanggungjawab pada mahasiswa pendidikan jasmani dinyatakan pada kategori positif. Hasil penelitian menunjukkan bahwa mahasiswa memiliki rasa tanggungjawab dalam melakukan pembelajaran secara mandiri atas tugas dan target pembelajaran yang harus dicapai. Menurut Zimmer (dalam Kurniawati 2011) ciri-ciri orang yang memiliki tanggung jawab yaitu: 1) memiliki komitmen yang tinggi, 2) mau bertanggung jawab, 3) energik, 4) berorientasi ke masa depan, 5) kemampuan memimpin, 6) mau belajar dari kegagalan, 7) yakin pada diri sendiri, dan 8) obsesi untuk mencapai prestasi yang lebih baik.

Pada indikator kelima, indikator berperilaku berdasarkan inisiatif sendiri yaitu sebesar 75,12\%. Dapat disimpulkan bahwa secara umum indikator berperilaku berdasarkan inisiatif sendiri pada mahasiswa pendidikan jasmani dinyatakan pada kategori positif. Hasil penelitian menunjukkan bahwa mahasiswa sudah memiliki inisiatif sendiri dalam melakukan pembelajaran secara mandiri dengan menggunaan metode belajar project based learning yang memudahkan proses pembelajaran dikarenakan sudah memahami apa yang harus dilakukan tanpa menunggu instruksi setiap saat dari pendidik.

Pada indikator kelima, indikator melakukan kontrol diri yaitu sebesar 71,79\%. Dapat disimpulkan bahwa secara umum indikator melakukan kontrol diri pada mahasiswa pendidikan jasmani dinyatakan pada 
kategori positif. Hasil penelitian menunjukkan bahwa mahasiswa melakukan kontrol diri dengan baik dalam melakukan pembelajaran secara mandiri dengan menggunaan metode belajar project based learning, yaitu dalam hal mengatur semua hal yang berkaitan dengan kebutuhan dalam pembelajaran. Menurut (Anggreini \& Mariyanti, 2014) pebelajar yang memiliki kontrol diri positif mampu mengelola informasi, mampu mengontrol emosi, dan mampu mengontrol perilaku emosional.

\section{KESIMPULAN}

Hasil pembahasan mengenai pembelajaran mahasiswa pendidikan jasmani dengan menggunakan metode belajar project based learning diperoleh data mengenai indikator kemandirian belajar yaitu pada pembahasan kemandirian belajar yang timbul dari penerapan metode pembelajaran belajar project based learning sebesar $76.37 \%$ dengan kategori sangat positif, dengan demikian dapat dikatakan bahwa mahasiswa melaksanakan pembelajaran dengan kemandirian belajar yang baik. Mahasiswa program studi pendidikan jasmani mampu melaksanakan proses pembelajaran dengan penuh tanggung jawab, rasa percaya diri dan dapat menyelesaikan permasalahan dengan kerja proyek yang secara tidak langsung melatih untuk bertindak maupun berpikir mandiri dan kreatif pada mata kuliah media pembelajaran penjas.

\section{DAFTAR PUSTAKA}

Afriana, J. (2015). Project Based Learning (PjBL).

Anggreini, R., \& Mariyanti, S. (2014). Hubungan Antara Kontrol Diri Dan Perilaku Konsumtif Mahasiswi Universitas Esa Unggul. Jurnal Psikologi Esa Unggul, 12(01).

Hidayati, K., \& Listyani, E. (2007). Improving Instruments-Regulated Learning. Yogyakarta: FMIPA UNY Mathematics Education Department.

Kurniawati, D. (2011). Upaya Meningkatkan Kemandirian Belajar Siswa Dalam Pembelajaran Matematika Melalui Model Cooperative Learning Tipe Kepala Bernomor Terstruktur Pada Siswa SMP N 2 Sewon Bantul.

Kusadi, N. M. R., Sriartha, I. P., \& Kertih, I. W. (2020). Model Pembelajaran Project Based Learning Terhadap Keterampilan Sosial Dan Berpikir Kreatif. Thinking Skills and Creativity Journal, 3(1), 18-27.

Lestari, T. (2016). Peningkatan Hasil Belajar Kompetensi Dasar Menyajikan Contoh-Contoh Ilustrasi Dengan Model Pembelajaran Project Based Learning Dan Metode Pembelajaran Demonstrasi Bagi Siswa Kelas XI Multimedia SMK Muhammadiyah Wonosari.

Nurfadilah, S., \& Hakim, D. L. (2019). Kemandirian Belajar Siswa dalam Pembelajaran Matematika. Prosiding Sesiomadika 2019, 1214-1223. http://journal.unsika.ac.id/index.php/sesiomadika

Rifky. (2020). Strategi Guru Dalam Menumbuhkan Kemandirian Belajar Peserta Didik Sekolah Dasar. EDUKATIF : Jurnal Ilmu Pendidikan, 2(1), 85-95.

Sevima. (2020). 6 Metode Pembelajaran Paling Efektif di Masa Pandemi Menurut Para Pakar. Sevima. https://sevima.com/6-metode-pembelajaran-paling-efektif-di-masa-pandemi-menurut-para-pakar/

Sudiana, R., Fatah, A., \& Khaerunnisa, E. (2017). Kemandirian Belajar Mahasiswa Melalui Pembelajaran Berbasis Virtual Class. Jurnal Penelitian Dan Pembelajaran Matematika, 10(1). https://doi.org/10.30870/jppm.v10i1.1292

Sudianto. (2018). Kemampuan Berpikir Kreatif Dan Kemandirian Belajar Siswa Pada Model Pembelajaran Project-Based Learning Berbantuan LMS Moodle.

Sugiyono. (2008). Metode Penelitian Pendidikan:(Pendekatan Kuantitatif, Kualitatif dan $R$ \& D). Bandung: Alfabeta. 
486 Kemandirian Belajar Melalui Metode Pembelajaran Project Based Learning Pada Mata Kuliah Media Pembelajaran Pendidikan Jasmani - Martiani

DOI: https://doi.org/10.31004/edukatif.v3i2.337

Turmuzi, M. (2021). Analisis Kompetensi Profesional dan Pedagogik Mahasiswa Pendidikan Matematika Dalam Implementasi Kurikulum 2013. Edukatif: Jurnal Ilmu Pendidikan, 3(2), 341-354. https://doi.org/10.31004/edukatif.v3i2.301

Utami, R. P., Probosari, R. M., \& Fatmawati, U. (2015). PENGARUH MODEL PEMBELAJARAN PROJECT BASED LEARNING BERBANTU INSTAGRAM TERHADAP KEMAMPUAN BERPIKIR KREATIF SISWA KELAS X SMA NEGERI 8 SURAKARTA. Jurnal Bio-Pedagogi, 4(1). https://jurnal.uns.ac.id/pdg/article/view/5364/4762

Yanti, S., \& Surya, E. (2017). Kemandirian Belajar Dalam Memaksimalkan Kualitas Pembelajaran. Medan: PPs Unimed.

Yunitasari, R., \& Hanifah, U. (2020). Pengaruh Pembelajaran Daring Terhadap Minat Belajar Siswa pada Masa COVID-19. Jurnal Ilmu Pendidikan, 2(3), 232-243. https://doi.org/10.31004/edukatif.v2i3.142 